\title{
Widespread Distribution of the Sycamore Seed Bug Belo- nochilus numenius (Hemiptera: Heteroptera: Lygaeidae) Throughout the Republic of North Macedonia
}

\author{
Katerina Srebrova ${ }^{1}$, Sterja Nacheski ${ }^{1}$, Kiril Sotirovski ${ }^{1 *}$
}

(1) "Ss. Cyril and Methodius" University, Faculty of Forestry, Aleksandar Makedonski bb, MK1000 Skopje, Republic of North Macedonia

* Correspondence: e-mail: kirils@sf.ukim.edu.mk

\begin{abstract}
Citation: SREBROVA K, NACHESKI S, SOTIROVSKI K 2019 Widespread Distribution of the Sycamore Seed Bug Belonochilus numenius (Hemiptera: Heteroptera: Lygaeidae) Throughout the Republic of North Macedonia. South-east Eur for 10 (2): 145-149. DOI: https://doi.org/10.15177/ seefor.19-19

Received: 11 Sep 2019; Revised: 4 Oct 2019; Accepted: 5 Oct 2019; Published online: 1 Nov 2019
\end{abstract}

\begin{abstract}
Background and Purpose: The sycamore seed bug, Belonochilus numenius (Say, 1831), was recorded for the first time in Europe in 2008, with finds in that same year in two separate locations in Spain and two in France. Since then, it has been reported to be present in 17 European countries. Once it reached Europe, the fast spread and establishment of this species was facilitated both by the increased plant trade and the relative frequency of plane trees (Platanus $\mathrm{x}$ acerifolia, $P$. orientalis and $P$. occidentalis) planted on a wide scale across the continent due to their popularity as urban and peri-urban trees. Materials and Methods: In the summer of 2019 we inspected urban, peri-urban and natural populations and groups of plane trees throughout North Macedonia, on a total of 44 sites, looking for presence of nymphs and adults of this insect on seed balls. We collected specimens and related data and made identification based on specific external characteristics typical of $B$. numenius.

Results: We report the first record of $B$. numenius in the Republic of North Macedonia from July 2019, from $P$. x acerifolia in Skopje. Furthermore, after inspecting plane trees throughout the country we report the presence of this insect in 29 cities and towns, 3 peri-urban and in 1 natural population of $P$. orientalis.

Conclusions: From the widespread distribution of this insect species, we conclude that it has entered the territory of North Macedonia many years prior, very likely soon after first records in Serbia in 2011 and Bulgaria in 2012, but has since been overlooked.
\end{abstract}

Keywords: alien insect species, Nearctic, plane trees, invasive

\section{INTRODUCTION}

Belonochilus numenius (Say, 1831), referred to as the sycamore seed bug or American sycamore seed bug, is naturally widely distributed in the USA and Mexico [1], between latitudes $15^{\circ}-45^{\circ} \mathrm{N}$, as per Ashlock (1967) [2], and in Canada in Ontario [3]. In 2011 it was recorded for the first time in the western state of British Columbia in Canada [4]. The main host plant species in North America are Platanus occidentalis and $P . \times$ acerifolia, but other species also mentioned as hosts by the early American investigators are
$P$. racemosa and $P$. wrighti, as well as Ambrosia trifida, Celtis occidentalis and Salix sp. [1].

This Nearctic species has recently entered and established itself in Europe, and has become invasive for the continent. The first record in 2008 was published in France by Matocq (2008), on finds of the species on the island of Corsica and the region of Languedoc $[2,5]$, and soon after in Spain on an earlier find from the region of Catalonia [2]. However, the earliest record in Europe is now considered to be the one from the islands of Palma de Mallorca in July of 2008 [5-7]. The first records, including those from Italy 
[8], all came from coastal regions of the Mediterranean, but this insect species quickly spread beyond and has been recorded in many countries and regions of the continent. Until to date, records of the presence of the species have been published in the following European countries - Spain and France in 2008; in 2010 Italy [8], Monaco [9] and Austria [10]; Czech Republic [11], Slovakia [12] and Serbia [13] in 2011; Switzerland [9], Hungary [14], Germany [15] and Bulgaria [13] in 2012; Madeira Islands of Portugal in 2014 [16]; Slovenia in 2015 [6]; Bosnia and Herzegovina in 2016 [17]; Albania in 2017 [18], and the latest first record coming from Greece in 2018 [19] with a sighting of a single individual adult specimen and no further finds despite active search after the first record. Additionally to these reports, detailed records of the spread and distribution of $B$. numenius have been published in Spain, France, Austria and Germany [5, 7, $9,20,21]$, where it is considered to be widely present.

It is worth mentioning that a find of a single specimen on the Azores (Portugal) determined as $B$. numenius (published by Ribes in 2010) is in fact a matter of misidentification of Orsillus depressus [7] and should therefore not be considered.

In early works in the USA, Heidemann (1902) and Van Duzee (1914) established that this species completes its life cycle on seed balls of $P$. occidentalis $[1,22]$. The insect is not considered as a threat to Platanus trees [7] and is not listed on either A1 or A2 list of the European and Mediterranean Plant Protection Organization for regulation of quarantine pests. However, it was officially declared as an urban pest for the first time in Badalona in Spain in 2011, and in 2015 it was declared as public nuisance in Barcelona, El Prat de Llobregat and Blanes [7]. This status was warranted because insects disturbed citizens due to their high numbers and amassing in houses, balconies, restaurants and the similar during outbreaks.

Plane trees are amongst the most common tree species used in urban greenery in North Macedonia, mainly $P$. orientlalis, but also $P . \mathrm{x}$ acerifolia, which has lately gained in popularity, and to a lesser extent $P$. occidentalis (Sotirovski, unpublished). The capital Skopje alone counts at least 3537 (incomplete tree census data for 2018; http://gis.skopje.gov. $\mathrm{mk} / \mathrm{zk} /$ ) and likely thousands more (Sotirovski, unpublished). On the other hand, there are only two towns (Delchevo and Pehchevo) which do not have at least a few plane trees incorporated in their urban landscape. Even in Krushevo, which is considered to be the town at the highest altitude in the Balkans at $1350 \mathrm{~m}$ a.s.I., there is an established oriental plane tree positioned in a prominent place of the town. Taking into consideration that there are also natural populations of $P$. orientalis along the Vardar river and several of its tributaries south of Skopje, around Ohrid and Dojran lakes, and in the footer of Belasica mountain [23], the numbers and distribution of plane trees in North Macedonia is such that the aerial distance of the most isolated and furthest subpopulation of plane trees (in Debar) to the nearest other subpopulation (Kichevo) in North Macedonia is less than $36 \mathrm{~km}$ (Sotirovski, unpublished). Furthermore, for the Debar plane tree subpopulation, we suspect that it might be positioned at a shorter distance from plane trees in Albania than from the ones in Kichevo. This, as well as imports and internal trade of plane trees for landscaping purposes, makes plane trees a perfect niche for the establishment and fast spread of $B$. numenius in North Macedonia.

Because of the wide dissemination and fast spread of this insect species in Europe and recent reports of its presence in neighboring countries, and after recording the first find in North Macedonia, we set to establish a snapshot of its current dissemination throughout the country.

\section{MATERIAL AND METHODS}

Our survey by visual inspection of host tree species and collection of specimens was conducted in the period between $10^{\text {th }}$ July 2019 (first record of $B$. numenius in North Macedonia) and $10^{\text {th }}$ September 2019. Survey and collection expeditions were completed throughout North Macedonia on plane trees ( $P$. orientalis, $P$. x acerifolia, and $P$. occidentalis) in urban settings in 34 cities and towns, 3 natural populations of $P$. orientalis, and 7 groups or isolated individual trees, or trees in peri-urban areas (Figure 1).

We identified and determined individuals as $B$. numenius by easily visible external characteristics described in works of European authors [2, 8] using various stereomicroscopic magnifications (Zeiss, Stemi 305). Documentation photos of specimens of adult and nymph stages were taken with Zeiss Axiocam 105 color camera.

Specimens were stored dry and in alcohol in the entomological collection of prof. Nacheski at the Faculty of Forestry in Skopje.

\section{RESULTS}

The first specimen of $B$. numenius in North Macedonia was collected on Platanus $x$ acerifolia in Skopje ( $N$ $41^{\circ} 58^{\prime} 27^{\prime \prime}$ E $21^{\circ} 28^{\prime} 15^{\prime \prime}$, leg. Srebrova, 10.07.2019). In total, nymph (Figure 2) and adult (Figure 3) specimens of $B$. numenius were registered and collected from 33 sites of the visited 44 locations in North Macedonia (Figure 1). In Skopje alone, $B$. numenius was registered and collected on 11 sites from various locations throughout the city from seed balls of all three plane species present in the country $-P$. orientalis, $P$. $x$ acerifolia and $P$. occidentalis. All records in Skopje are listed as one in this publication (Figure 1).

In many cases, numerous individuals were recorded per single seed ball, including both adults and larvae (up to 13 individuals per single seed ball). On the other hand, there were cases where hundreds of seed balls had to be inspected per location (or tree) before registering the presence of a single specimen of $B$. numenius.

The highest altitude from which viable specimens were collected was $964 \mathrm{~m}$ a.s.I. in the town of Kratovo. On the contrary, the single plane tree in Krushevo was thoroughly inspected and did not bare any B. numenius, and similarly no presence was registered in Berovo (where only several seed balls from 1 of the 2 present trees were in reach). The southernmost finds in the country were near Dojran lake, close to the border with Greece. 


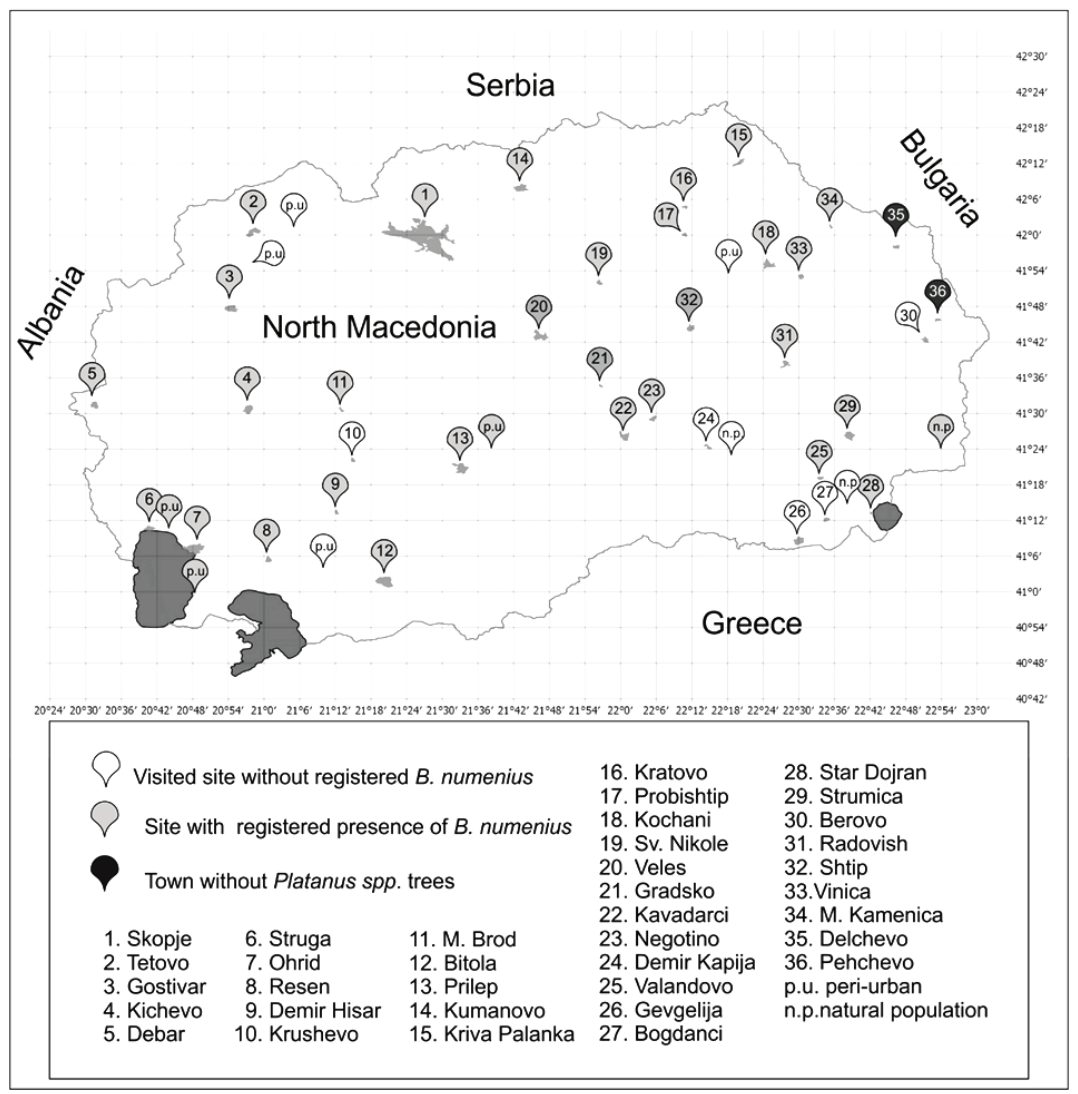

FIGURE 1. Inspected sites and records of Belonochilus numenius in North Macedonia in 2019.

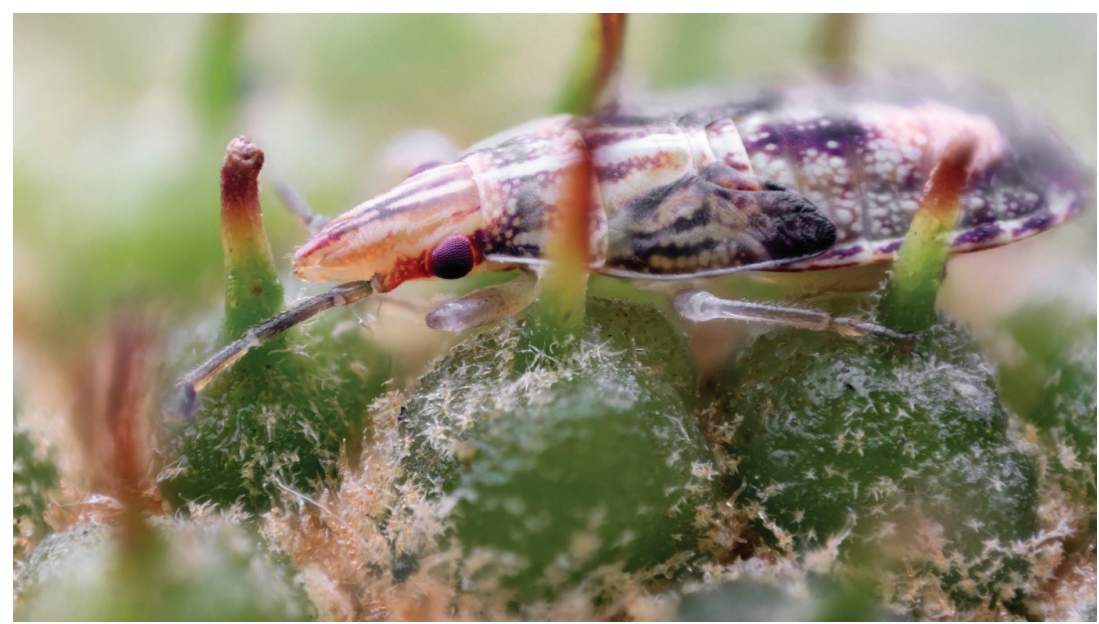

FIGURE 2. Nymph of B. numenius collected in Skopje (photo: Velian Jagev) 


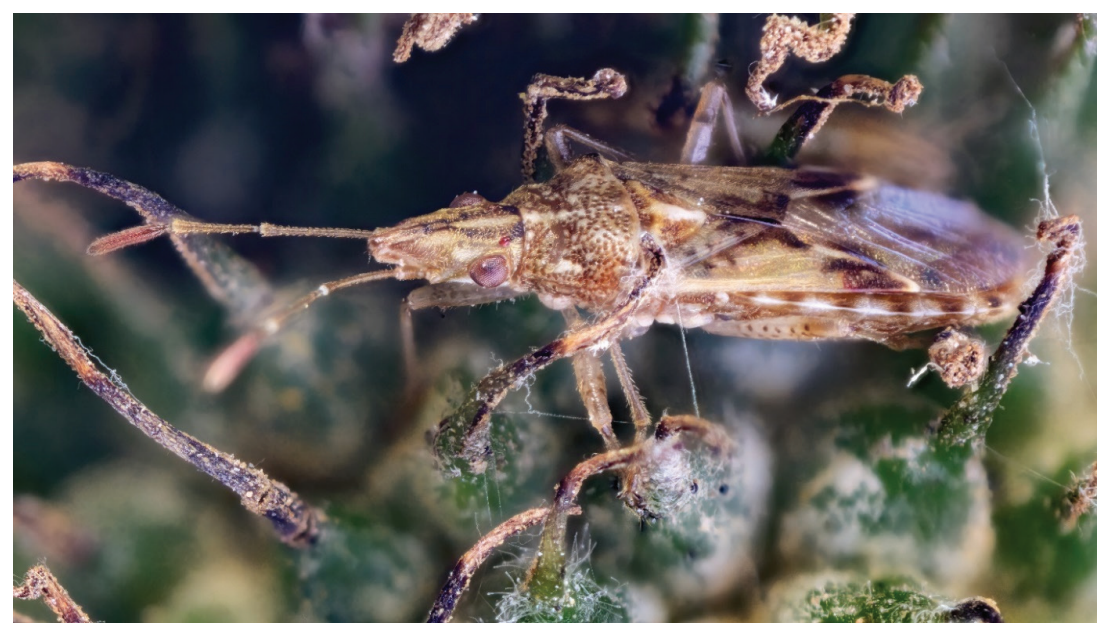

FIGURE 3. Adult specimen of $B$. numenius (photo: Velian Jagev)

\section{DISCUSSION AND CONCLUSIONS}

Having in mind that we registered the presence of this insect on most of the visited sites, it can be stated that it has been overlooked for many years, likely entering the territory of North Macedonia not long after being registered in Serbia and Bulgaria in 2011 and 2012, respectively. The main modes of dispersal and spread of the sycamore seed bug are flight, winds and passive transport, mainly by plant trade, as it is the case with other insects [24-26], and any of these modes could have been responsible for its entry into North Macedonia, either from neighboring countries, or from farther countries by imports of plant material. All of these modes have also likely played a role in fast dissemination and establishment of this Nearctic species in North Macedonia. Furthermore, the possibility of multiple introductions is very high by means of trade and transport of plant material, which is also applicable for other regions and countries in Europe, especially since this species is now widespread and established throughout the continent.

Although we did not find the presence of $B$. numenius in Demir Kapija (town and nearby natural population), Gevgelija and Bogdanci, we are inclined to believe that a more resolute inspection would likely reveal the presence of this insect species in some, if not all, subpopulations where we did not register it in 2019. Similarly, finding B. numenius near Dojran, very close to the border with Greece, is an indicator that further finds in Greece are only a matter of a more thorough search in this region.

Although this insect species is not considered to be a threat to its host species, it needs to be followed and eventually analyzed in the context of its relationship with insect species considered to be in their natural range in the Balkans, Arocatus roeselii (Schilling, 1829) and A. longiceps (Stål, 1872) [27, 28], which occupy and are dependent on the same ecological niche, i.e. seed balls of Platanus. It should be noted that during our inspections we recorded widespread presence of Arocatus spp., often occupying the same trees, and in rare cases both $B$. numenius and Arocatus sp. were present on the same seed balls. Weather the establishment of $B$. numenius will have any effects on populations of Arocatus spp. and whether potential mass populations of $B$. numenius can have any negative impact on the reproduction of natural populations of plane trees through seed propagation, as well as other wider environmental implications, remains to be investigated in the future.

\section{Acknowledgements}

We express our gratitude to Velian Jagev for the photographs, and Boshko Cvetkovski, Mihajlo Risteski and Karolina Jangelova for help during the collection of specimens.

\section{REFERENCES}

1. WHEELER JR A 1984 Seasonal history, habits, and immature stages of Belonochilus numenius (Hemiptera: Lygaeidae) [Pennsylvania]. Proceedings Entomological Society of Washington 86 (4): 790-796

2. GESSÉ F, RIBES J, GOULA M 2009 Belonochilus numenius, the sycamore seed bug, new record for the Iberian fauna. $B$ Insectol 62 (1): 121-123
3. MAW HEL, FOOTTIT RG, HAMILTON KA, SCUDDER GG 2000 Checklist of the Hemiptera of Canada and Alaska. NRC Research Press, Ottawa, Canada, $220 p$

4. SCUDDER GG 2012 Additional provincial and state records for Heteroptera (Hemiptera) in Canada and the United States. Journal of the Entomological Society of British Columbia 109: 55-69 
5. BAENA M, TORRES JL 2012 Nuevos datos sobre heterópteros exóticos en España y Francia: Tempyra biguttula STÅL, 1874, Belonochilus numenius (Say, 1832) y Zelus renardii (Kolenati, 1856)(Heteroptera: Rhyparochromidae, Orsillidae, Reduviidae). Boletín de la Asociación española de Entomología 36 (3-4): 351-360

6. GOGALA A, KAMIN J, ZDEŠAR M 2016 Three new records of Heteroptera in Slovenia. Acta Entomologica Slovenica 24 (1): 55-58

7. RIBA JM, MARTÍ I, GOULA M 2015 Updating data on the sycamore seed bug, Belonochilus numenius (Say, 1832) (Hemiptera: Lygaeidae) in Spain. Butlletí de la Institució Catalana d'Història Natural 79: 157-163

8. KÜCHLER S, STRAUß G 2010 Belonochilus numenius (Say, 1832)(Heteroptera: Lygaeidae)-bald auch in Mitteleuropa? Beiträge zur Entomofaunistik 11: 27-33

9. WERNER D 2014 Die amerikanische Platanen-Samen-Wanze Belonochilus numenius (Say, 1831)(Heteroptera: Lygaeidae, Orsillinae) als Neozoon in Europa und in Deutschland: Verbreitung und Biologie. Andrias 20: 245-250

10. RABITSCH W, BRÄU M, FRIESS T 2011 Belonochilus numenius (Say, 1832)(Heteroptera: Lygaeidae) has reached Austria. Beiträge zur Entomofaunistik 12: 148-149

11. KMENT P, HRADIL K, BAŇAŘ P, BALVÍN O, CUNEV J, DITRICH T, JINDRA Z, ROHÁČOVÁ M, STRAKA M, SYCHRA J 2013 New and interesting records of true bugs (Hemiptera: Heteroptera) from the Czech Republic and Slovakia V. Acta Musei Moraviae, Scientiae Biologicae 98 (2): 495-541

12. KMENT P, CUNEV J 2013 First record of the alien seed bug Belonochilus numenius (Hemiptera: Heteroptera: Lygaeidae) in Slovakia. Entomofauna Carpathica 25 (2): 15-20

13. PROTIĆ L, ŠEAT J 2016 First records of the alien sycamore seed bug Belonochilus numenius in Serbia (Heteroptera: Lygaeidae). Acta Entomologica Serbica 21: 13-19

14. TORMA A 2012 First record of the alien sycamore seed bug Belonochilus numenius (Heteroptera: Lygaeidae) in Hungary. Növényvédelem 48 (10): 467-468

15. WERNER DJ, BRANDNER J, MULLER A, ZAPF M 2013 Ein Fund von Belonochilus numenius (Say, 1831) in Deutschland (Heteroptera: Lygaeidae) mit Diskussion zum Jahr der Erstbeschreibung der Art. Heteropteron 39: 37-39
16. RABITSCH W, HEISS E 2015 Belonochilus numenius (Say, 1832), the sycamore seed-bug (Hemiptera: Heteroptera: Lygaeidae), new to Madeira. Heteropterus Revista de Entomología 15 (1): 83-86

17. KULIJER D, MILJEVIC I 2016 First report of Belonochilus numenius (Say, 1832) in Bosnia and Herzegovina (Heteroptera, Lygaeidae). Folia Historico-Naturalia Musei Matraensis 40: 6163

18. RABITSCH W 2018 Snapshot of the terrestrial true bug fauna of the Pocem floodplains (Insecta: Hemiptera: Heteroptera). Acta ZooBot Austria 155: 251-256

19. DAVRANOGLOU L-R, KOUTSOUKOS V 2018 First record of the Nearctic sycamore seed bug Belonochilus numenius (Hemiptera: Heteroptera: Lygaeidae) from Greece. Ecologica Montenegrina 16: 32-33

20. WERNER DJ 2017 New records of Belonochilus numenius (SAY, 1831 ) in Germany and fundamental statements about the species. Heteropteron 49: 21-22

21. HILPOLD A 2018 Die Platanen-Samenwanze Belonochilus numenius (SAY, 1832)(Heteroptera: Lygaeidae) - neu für Südtirol. Gredleriana 18: 129-130

22. SWEET MH 1960 The seed bugs: a contribution to the feeding habits of the Lygaeidae (Hemiptera: Heteroptera). Ann Entomol Soc Am 53 (3): 317-321. DOI: https://doi.org/10.1093/ aesa/53.3.317

23. DZEKOV S 1988 Dendrology. Ss. Cyril and Methodius University, $538 \mathrm{p}$

24. 24. MUTUN S, CEYHAN Z, SÖZEN C 2009 Invasion by the oak lace bug, Corythucha arcuata (Say)(Heteroptera: Tingidae), in Turkey. Turk J Zool 33 (3): 263-268. DOI: https://doi. org/10.3906/zoo-0806-13

25. 25. IZHEVSKY S, MASLYAKOV VY 2010 New invasions of alien insects into the European part of Russia. Russian Journal of Biological Invasions 1 (2): 68-73. DOI: https://doi.org/10.1134/ $\underline{\mathrm{S} 2075111710020037}$

26. MACELJSKI M 1986 Current status of Corythuca ciliata in Europe 1. EPPO Bulletin 16 (4): 621-624. DOI: https://doi. org/10.1111/i.1365-2338.1986.tb00332.x

27. BIANCHI Z, ŠTEPANOVIČOVÁ O 2003 Some notes on the occurrence of Arocatus genus (Heteroptera, Lygaeidae) in Slovakia. Folia Faunistica Slovaca 8: 75-77

28. GAO C, KONDOROSY E, BU W 2013 A review of the genus Arocatus from Palearctic and Oriental regions (Hemiptera, Heteroptera: Lygaidae). Raffles B Zool 61 (2): 687-704 
